\title{
KOORDINACIJOS IR PUSIAUSVYROS PRATIMAI PAGERINA SENYVO AMŽIAUS ASMENŲ NE TIK FUNKCINI PAJËGUMĄ, BET IR KOGNITYVINES FUNKCIJAS
}

\author{
Inga Muntianaitė1, Fausta Blužaitė ${ }^{1,2}$, Jurga Indriūnienè $\dot{1}^{1,2}$, Ramunè Žilinskiené $\dot{ }^{3}$, \\ Akvilè Nainaité ${ }^{1}$
}

\begin{abstract}
${ }^{1}$ Vilniaus universiteto Medicinos fakulteto Reabilitacijos, fizinès ir sporto medicinos katedra, ${ }^{2}$ Vilniaus universiteto ligoninès Santariškiu kliniku Fizinès medicinos ir reabilitacijos centras, ${ }^{3}$ Vilniaus universitetas, Sveikatos ir sporto centras
\end{abstract}

Raktažodžiai: senyvas amžius, koordinacijos ir pusiausvyros pratimai, funkcinis pajëgumas, kognityvinès funkcijos

\begin{abstract}
Santrauka
Tyrimo tikslas: nustatyti taikomosios fizinès veiklos, pagrịstos koordinacijos ir pusiausvyros pratimais, poveiki senyvo amžiaus asmenų funkciniam pajėgumui ir kognityvinėms funkcijoms.

Tiriamujų kontingentas: tyrime dalyvavo 40 vyresnio amžiaus asmenų, kurių amžiaus vidurkis buvo $71,6 \pm 6,9$ metai. Tiriamieji buvo suskirstyti į 2 grupes: tiriamają - mankštos grupę $(\mathrm{n}=20$; amžius $71,35 \pm 6,52)$ ir kontrolinę - nesimankštinančiųu grupę ( $\mathrm{n}=20 ; 73,55 \pm 5,47$ metai). Tiriamajai grupei 8 savaites buvo taikoma fizinès veiklos programa, parengta pusiausvyros ir koordinacijos lavinimo tikslais. Užsièmimai vyko 2 kartus per savaitę, trukmè $40-50 \mathrm{~min}$.

Tyrimo metodai: trumpasis fizinès funkcijos testu rinkinys, 5 žodžių testas, skaičių sujungimo testas, objektyvus (bendrasis) pažintinių funkcijų testas, subjektyvus pažintinių funkcijų testas, statistinè duomenų analizè.

Rezultatai ir išvados: po pusiausvyros ir koordinacijos lavinimo programos tiriamosios grupès funkcinio pajègumo rezultatai statistiškai reikšmingai pagerèjo ir skyrèsi nuo kontrolinès grupès $(p<0,05)$ : tiriamosios grupès bendra Trumpojo fizinès funkcijos testų rinkinio balų suma antro tyrimo metu buvo $11,80 \pm 1,06$ balų, kontrolinès grupès $-8,95 \pm$ 1,15 balo $(\mathrm{p}<0,05)$. Tiriamosios grupes objektyvus ir subjektyvus kognityvinių funkcijų lygis pagerè-
\end{abstract}

jo labiau nei kontrolinès grupès $(\mathrm{p}<0,05)$; tiriamosios grupés dalyvių trumpalaikès atminties ir ilgalaikès atminties rezultatai II tyrimo metu buvo geresni nei kontrolinès grupés $(\mathrm{p}<0,05)$. Tiriamosios grupės vykdomųjų kognityvinių funkcijų rezultatai, po pusiausvyros ir koordinacijos lavinimo programos, statistiškai reikšmingai pagerèjo, tačiau tarp grupių nesiskyrè $(p=0,074)$. Išanalizuoti atlikto tyrimo duomenys rodo, jog taikomosios fizinès veiklos programa, parengta pusiausvyros ir koordinacijos tikslais, daro teigiamą poveikị senyvo amžiaus asmenų funkciniam pajègumui ir kognityvinèms funkcijoms.

\section{Ivadas}

Lietuvoje, kaip ir daugelyje Europos šalių, viena aktualiausių visuomenès problemų yra senèjimas. Stebint dabartines tendencijas ir toliau numatomas vyresnių nei $60 \mathrm{~m}$. amžiaus gyventojų skaičiaus augimas. Visuomenès senejjimo procesas turi itakos ne tik socialiniams, ekonominiams, bet ir psichologiniams aspektams. Dèl organizmo senejjimo procesų vyresniame amžiuje mažèja ne tik savarankiškumas, funkcinis pajègumas, tačiau prastesnès darosi ir kognityvinès funkcijos, kurios pasireiškia susilpnejjusia atmintimi, laiko ir erdvès nesuvokimu, prasta orientacija, žmonių neatpažinimu $[1,2]$.

Kasdieninis fizinis aktyvumas vaidina svarbų vaidmenį senyvo amžiaus žmonių gyvenimo kokybei ir gyvenimo trukmei $[3,4]$, teigiamai veikia fizinę sveikatą, pagerina judèjimo funkciją, pusiausvyrą ir koordinaciją, mažina griuvimų riziką, asmenys ilgiau gali išlikti nepriklausomi vyresniame amžiuje [5]. Fizinè veikla taip pat gerina ir kognityvines funkcijas [6], tačiau mokslinèje literatūro- 
je mažai ištyrinèta, koki poveiki pusiausvyros pratimai ir koordinacijos lavinimas gali turèti asmenų susilpnejjusios atminties, dèmesio koncentracijos, sutrikusio orientavimosi laike ir erdveje pakitimams, kurie neabejotinai veikia žmogaus kasdienybę, socialinius ryšius, gyvenimo kokybę ir pasitenkinimą gyvenimu.

Tyrimo tikslas - nustatyti taikomosios fizinès veiklos, pagristos koordinacijos ir pusiausvyros pratimais, poveiki senyvo amžiaus asmenų funkciniam pajègumui ir kognityvinèms funkcijoms.

\section{Tyrimo metodika}

Tyrimas buvo atliktas Vilniaus universiteto Medicinos fakulteto Reabilitacijos, fizinès ir sporto medicinos katedroje bei Vilniaus universiteto ligoninès Santariškių klinikų Reabilitacijos, fizinès ir sporto medicinos centre . I tyrimą buvo įtraukti asmenys atitinkantys įtraukimo kriterijus: amžius $60 \mathrm{~m}$ ir vyresni, savanoriškas sutikimas dalyvauti tyrime, nedirbantys asmenys, trumpojo protinès būklès tyrimo rezultatas $>11$ balų. Neįtraukimo ị tyrimą kriterijai buvo: jaunesni nei 60 metų, dirbantys asmenys, trumpojo protinès būklès tyrimo rezultatas $<11$ balų, atramos - judèjimo sistemos ir nervų ligos, trikdančios judejjimo funkcijas.

Tyrime dalyvauti buvo pasiūlyta 52 vyresnio amžiaus vyrams ir moterims. I tyrimą nebuvo įtraukti 12 asmenų: 6 neatitiko ịtraukimo ị tyrimą kriterijų, 4 nesutiko dalyvauti visuose tyrimo etapuose, 2 nesilaikè programos lankymo tvarkaraščio. Iš viso tyrime dalyvavo 40 vyresnio amžiaus asmenų, savanoriškai sutikusių dalyvauti tyrime ir atitinkančių ịtraukimo ị tyrimą kriterijus, iš kurių buvo 9 vyrai ir 31 moteris. Bendras tiriamujų amžiaus vidurkis tyrimo pradžioje buvo $71,6 \pm 6,9$ metų. Jauniausiam tyrimo dalyviui buvo 60 metų, vyriausiam - 82 metai.

Visi tiriamieji buvo supažindinti su tyrimo tikslais, tyrimo testavimo procedūromis, tyrimo nauda ir galimais nepatogumais. Tiriamieji buvo suskirstyti i 2 grupes: tiriamają (TG) ir kontrolinę (KG) grupes. Tiriamajai grupei 8 savaites buvo taikoma fizinès veiklos programa, parengta pusiausvyros ir koordinacijos lavinimo tikslais. Užsièmimai vyko 2 kartus per savaitę, trukmè $40-50 \mathrm{~min}$. Visi pratimai fizinès veiklos programoje buvo sudaryti remiantis Amerikos senejimo instituto [80] ir PSO parengtomis rekomendacijomis užsiimti fizine veikla.

Prieš pradedant vykdyti taikomosios fizinès veiklos programą tiriamosios grupès dalyvių buvo prašoma užpildyti Pasirengimo fiziniam aktyvumui klausimyną (angl. PAR-Q-Physical Activity Readiness Questionaire), kad būtų galima numatyti tikètinas sveikatos komplikacijas ir jų išvengti. PAR-Q klausimynas - pasirengimo fiziniam aktyvumui nustatymo metodas, patvirtintas Britanijos sveikatos departamento. Klausimynas parodo tiriamųjų galimybes at- likti kai kuriuos fizinius pratimus. Tai padeda parinkti tam tikrą fizinị krūvị, intensyvumą, fizinio užimtumo veiklos formos priimtiniausias tiriamajam žinant kontraindikuotinus veiksnius. PAR-Q anketą sudaro 7 klausimai, i kuriuos tiriamasis gali pasirinkti vieną iš dviejų atsakymų: taip arba ne. Kuo daugiau klausimų tiriamasis atsako teigiamai, tuo didesnè rizika atliekant ịvairius fizinius pratimus [7].

Funkcinio pajègumo vertinimas. Tiriamųų funkcinis pajegumas buvo vertinamas atliekant Trumpaji fizinès funkcijos testų rinkini (angl. Short physical performance battery, $S P P B)$. Testų rinkini sudaro eisenos greičio, gebejjimo atsistoti nuo kẻdès, gebẻjimo išlaikyti pusiausvyrą vis sudètingesnèse padètyse ịvertinimai. Trumpojo fizinès funkcijos testo balų suma skaičiuojama sudejjus visose užduotyse surinktus balus. Maksimali trumpojo fizinès funkcijos testų rinkinio balų suma lygi 12 balų.

Pusiausvyra buvo vertinama tiriamajam stovint ir stengiantis išlaikyti pusiausvyrą po 10 sekundžiu trijose vis daugiau pastangų reikalaujančiose padètyse, t.y. tandeminejje padètyje, pusiau tandeminèje padètyje ir stovèjimas paprastai suglaustomis kojomis.

Eisenos greitis buvo vertinamas 4 metru èjimo testu: greitis vertinamas matuojant laiką sekundemis, per kurị tiriamasis bus prašomas sau ịprastu greičiu nueiti 4 metrus. Šis testas atspindi visą kompleksą matavimų: jègą, greiti ir dinaminę pusiausvyrą. Testas susideda iš pakilimo nuo kèdès, 4 metrų nuejjimo, apsisukimo apie žymeklį ir sugrịžimo prie kẻdès.

Gebejjimas atsistoti vertinamas atliekant 5 kartu atsistojimo - atsisédimo testą, t.y. tiriamasis buvo prašomas atsisèsti ir atsistoti nuo kèdès taip greitai, kaip gali, laikydamas sukryžiuotas rankas ant krūtinės ir nesiremdamas i aplinkinius daiktus.

Kognityvinių funkcijų vertinimas. Kognityvinès funkcijos buvo vertinamos keliais testais: - Objektyviu (bendrasis) pažintinių funkcijų testu - 6 CIT - (angl. Six item cognitive impairment test); Subjektyviu pažintiniu funkcijų testu - CFQ - (angl. The cognitive failures questionnaire); 5 žodžiu testu (angl. 5 words test); Skaičių sujungimo testu (angl. Trail making test $A-T M T-A$ ).

Siekiant objektyviomis metodikomis įvertinti tiriamųjų bendrą pažintinių funkcijų lygị buvo naudojamas 6 CIT klausimynas. 6 CIT klausimyną sudaro šeši klausimai: vienas apie atmintį, du apie demesį - skaičiavimą ir trys orientaciją vertinantys klausimai. Klausimynas vertinamas nuo vieno iki 28 balų, didesnis balas reiškia didesni pažintinių funkcijų pakitimą. Lietuviškoje literatūroje patiekti 6 CIT iverčiai yra tokie: 0 - 7 balai: normali veikla, $8-9$ balai: abejotini pažintinių funkcijų pakitimai, 10 - 28 balai: vidutiniai/sunkūs pažintinių funkcijų pakitimai.

Subjektyvios kognityvinès funkcijos buvo vertinamos 
naudojant CFQ metodiką. Klausimynas sudarytas iš dviejų dalių - viena grupe klausimų yra susijusi su atmintimi, kita dalis orientuota $\mathfrak{i}$ susijusias pažintines funkcijas: veiklos planavimą, dèmesio koncentraciją, gebejjimą veikti greitai ir efektyviai. Paskutinis klausimas yra susijęs su tiriamųju jaučiamais neigiamais jausmais. Atliekant ịvertinimą, tiriamasis daugiausia gali surinkti 25 balus ir tai rodo labai ryškų kognityvinių funkcijų blogèjimą. Surinkus mažiausią

1 lentelè. Tyrimo dalyvių trumpojo fizinès funkcijos testo rezultatai ${ }^{*}<0,005$; $p$-reikšmingumo lygmuo; $S N$ - standartinis nuokrypis

\begin{tabular}{|c|c|c|c|c|}
\hline $\begin{array}{c}\text { Tyrimo skalès, } \\
\text { matavimo vienetai }\end{array}$ & Laikotarpis & $\begin{array}{c}\text { Tiriamoji } \\
\text { grupé } \\
\text { vidurkis } \pm \text { SN }\end{array}$ & $\begin{array}{l}\text { Kontroliné } \\
\text { grupé } \\
\text { vidurkis } \pm \mathrm{SN}\end{array}$ & $\begin{array}{l}\mathrm{p}(\operatorname{tarp} \\
\text { grupių) }\end{array}$ \\
\hline \multicolumn{5}{|l|}{$\begin{array}{l}\text { Trumpasis fizinės funkcijos } \\
\text { testų rinkinys (balai) }\end{array}$} \\
\hline \multirow{3}{*}{ Padetis suglaustomis pèdomis } & I tyrimas & $0,95 \pm 0,22$ & $0,95 \pm 0,22$ & 1,000 \\
\hline & II tyrimas & $1,00 \pm 0,00$ & $1,00 \pm 0,00$ & 1,000 \\
\hline & $\mathrm{p}$ (tarp I ir II tyrimo) & 0,317 & 0,317 & \\
\hline \multirow{3}{*}{ Pusiau tandeminè pédu padètis } & I tyrimas & $0,95 \pm 0,22$ & $0,85 \pm 0,37$ & 0,298 \\
\hline & II tyrimas & $1,00 \pm 0,00$ & $0,85 \pm 0,37$ & 0,075 \\
\hline & $\mathrm{p}$ (tarp I ir II tyrimo) & 0,317 & 0,846 & \\
\hline \multirow{3}{*}{ Tandeminè pèdu padètis } & I tyrimas & $1,45 \pm 0,60$ & $1,40 \pm 0,50$ & 0,665 \\
\hline & II tyrimas & $1,85 \pm 0,37$ & $1,40 \pm 0,50$ & $0,004^{*}$ \\
\hline & $\mathrm{p}($ tarp I ir II tyrimo) & $0,005^{*}$ & 0,812 & \\
\hline \multirow{3}{*}{$\begin{array}{l}4 \text { metru ejimas (eisenos } \\
\text { greitis) }\end{array}$} & I tyrimas & $2,80 \pm 0,41$ & $2,80 \pm 0,70$ & 0,847 \\
\hline & II tyrimas & $3,85 \pm 0,37$ & $3,10 \pm 0,55$ & $<0,001^{*}$ \\
\hline & $\mathrm{p}$ (tarp I ir II tyrimo) & $<0,001^{*}$ & 0,083 & \\
\hline \multirow{3}{*}{$\begin{array}{l}\text { Atsistojimai пио kèdès } \\
\text { (gebèjimas atsistoti) }\end{array}$} & I tyrimas & $2,75 \pm 0,64$ & $2,55 \pm 0,60$ & 0,310 \\
\hline & II tyrimas & $3,80 \pm 0,41$ & $2,60 \pm 0,75$ & $<0,001^{*}$ \\
\hline & $\mathrm{p}(\operatorname{tarp}$ I ir II tyrimo) & $<0,001^{*}$ & 0,763 & \\
\hline \multirow{3}{*}{ Bendra testo balų suma } & I tyrimas & $8,95 \pm 1,05$ & $8,55 \pm 1,28$ & 0,185 \\
\hline & II tyrimas & $11,80 \pm 1,06$ & $8,95 \pm 1,15$ & $<0,001^{*}$ \\
\hline & $\mathrm{p}$ (tarp I ir II tyrimo) & $<0,001 *$ & 0,099 & \\
\hline
\end{tabular}

2 lentelė. Tyrimo dalyvių objektyvių ir subjektyvių kognityvinių funkcijų rezultatai ${ }^{*} p<0,005 ; p$-reikšmingumo lygmuo; $S N$ - standartinis nuokrypis

\begin{tabular}{|c|c|c|c|c|}
\hline \multirow{2}{*}{$\begin{array}{c}\text { Tyrimo skalès, } \\
\text { matavimo vienetai }\end{array}$} & Laikotarpis & $\begin{array}{c}\text { Tiriamoji grupé } \\
\text { Vidurkis } \pm \text { SN }\end{array}$ & $\begin{array}{c}\text { Kontrolinè grupé } \\
\text { Vidurkis } \pm \text { SN }\end{array}$ & $\begin{array}{c}\mathrm{p} \text { (tarp } \\
\text { grupių) }\end{array}$ \\
\hline $\begin{array}{c}\text { Obejktyvus pažintiniu } \\
\text { funkcijų lygis, balai }\end{array}$ & I tyrimas & $10,00 \pm 1,92$ & $9,20 \pm 1,58$ & 0,165 \\
\cline { 2 - 5 } & II tyrimas & $6,95 \pm 0,945$ & $8,95 \pm 1,61$ & $<0,001^{*}$ \\
\cline { 2 - 5 } $\begin{array}{c}\text { Subjektyvus } \\
\text { pažintinių funkcijų } \\
\text { lygis, balai }\end{array}$ & I tyrimas & $13,00 \pm 4,81$ & $12,55 \pm 4,19$ & 0,586 \\
\cline { 2 - 5 } & II tyrimas & $5,50 \pm 5,15$ & $12,50 \pm 4,42$ & $<0,001^{*}$ \\
\cline { 2 - 5 } & $\mathrm{p}$ (tarp I ir II tyrimo) & $<0,001^{*}$ & 0,942 & \\
\hline
\end{tabular}

galimą taškų skaičių (0 balų) - tiriamujų kognityvinès funkcijos yra nesusilpnejusios.

Trumpalaikè ir ilgalaikè atmintis buvo vertinama 5 žodžių testu. Trumpalaikè atmintis vertinama pagal tai, kaip asmuo susikoncentruoja ị jam sakomus žodžius ir sugeba juos iš karto atsiminti ir pakartoti. Už 5 atsimintus ir išvardintus žodžius surenkami 5 balai, jei išvardijama mažiau žodžių, atitinkamai surenkama ir mažiau balų. Tokia balų sistema buvo vertinama ir ilgalaikè atmintis. Vertinant ilgalaikę atmintį išvardijus tiriamajam 5 žodžius, paprašoma tiriamojo juos prisiminti, užsiimama su tiriamuoju kita veikla (palaukiama kol praeis šiek tiek laiko). Daugiausia vertinime galima surinkti 5 balus (jei asmuo išvardija visus 5 žodžius).

Skaičiu sujungimo testu (angl. Trail Making Test - A, TMT_A) buvo vertinami dalyvių vykdomosios veiklos (vaizdo, reakcijos ir greičio) pažintiniai gebejimai. Testas naudojamas kaip viena iš jautriausių priemonių kognityvinių funkcijų klinikinès praktikos bandymuose. Testo atlikimas vertinamas sekundèmis, per kokị laiką tiriamasis paeiliui sujungė skaičius nuo 1 iki 25. Testas nevertinamas, jei tiriamasis atlieka ši testą ilgiau nei 5 minutes, taip pat, jei skaičiai sujungti nepaeiliui, su klaidomis. Šis testas naudojamas ne tik kognityvinių funkcijų ištyrimui senyvo amžiaus asmenims be specifinių diagnozių, bet ir nustatant pradines ligos stadijas (Alzheimerio, demencijos) bei potrauminių rodiklių stebejjimui.

Statistinė duomenų analizė. Statistinè duomenų analizė atlikta naudojant SPSS 20.0 for Windows programu paketą. Aprašant duomenis kiekybiniams kintamiesiems nurodyti vidurkiai ir standartiniai nuokrypiai (SN). Dvieju grupių kintamujų vidurkių skirtumai buvo palyginti naudojant Mann Whitney U kriterijų; vienos ir tos pačios grupès kintamujų vidurkiai buvo palyginti naudojant Wilcoxon kriterijų. Patikimumo kriterijų vertinimas buvo laikomas statistikai reikšmingu, jei $\mathrm{p}$ reikšmė buvo mažesnè už $0,05(\mathrm{p}<0,05)$.

\section{Rezultatai}

Ivertinus Trumpojo fizinès funkcijos testų rinkinio atskiras užduotis pirmojo ir antrojo tyrimo metu (1 lentelè), nustatyti tiria- 


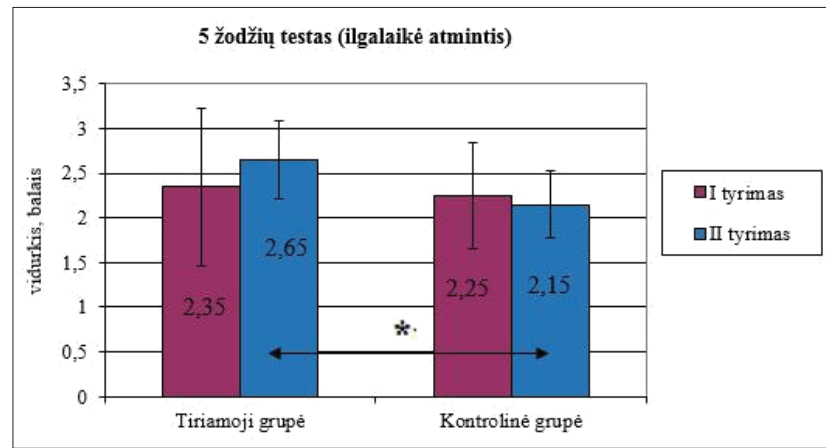

1 pav. Tyrimo dalyvių trumpalaikès atminties rezultatai ${ }^{*} p<0,005$;

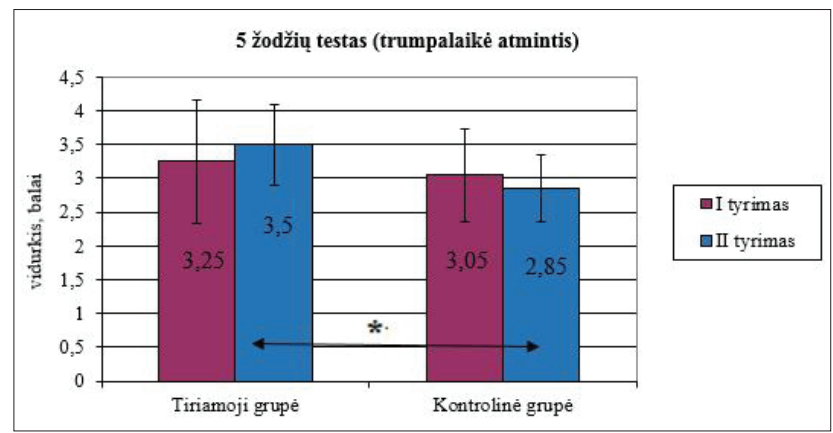

2 pav. Tyrimo dalyvių ilgalaikès atminties rezultatai. ${ }^{*} p<0,005$

mojoje grupejje statistiškai reikšmingi pokyčiai tandeminès pẻdų padèties užduotyje (pagerèjo 0,40 $\pm 0,50$ balais), 4 metrų èjimo (pagerėjo 1,05 \pm 0,39 balais), atsistojimo nuo kèdès ( pagerejo $1,05 \pm 0,510$ balais ). Bendra testo balų suma šioje grupejje pakito $2,85 \pm 1,27$ balais $(\mathrm{p}<0,05)$. Kontrolinèje grupeje funkcinis pajegumas nepakito $(\mathrm{p}>$ $0,05)$. Palyginus antro tyrimo gautus rezultatus, nustatytas statistiškai reikšmingas skirtumas tarp tiriamosios ir kontrolinès grupès, vertinant tandeminę padètį, 4 metrų ejimą, atsistojimą nuo kèdès ir bendrą testo balų sumą.

Vertinant objektyvias ir subjektyvias tiriamujų kognityvines funkcijas, rezultatai parode (2 lentelè), jog tiriamosios ir kontrolinès grupių balų suma I tyrimo metu tarpusavyje nesiskyrè ( $p>0,05)$. Tačiau vertinant šias funkcijas II tyrimo metu, tiriamojoje grupejje balų skaičius statistiškai reikšmingai sumažèjo, o kontrolinèje grupejje - statistiškai reikšmingai nepakito. Lyginant rezultatus tarp grupių nustatyta, kad objektyvios ir subejktyvios kognityvinès funkcijos buvo statistiškai reikšmingai geresnès nei kontrolinès grupès II tyrimo metu.

Trumpalaikè ir ilgalaikè atmintis buvo vertinama 5 žodžių testu (1, 2 pav.). II tyrimo metu nustatyta, jog tiriamosios grupès trumpalaikès ir ilgalaikès atminties rezultatai yra statistiškai reikšmingai geresni nei kontrolinès grupès. Tačiau grupèse reikšmingo pokyčio nebuvo lyginant I ir II

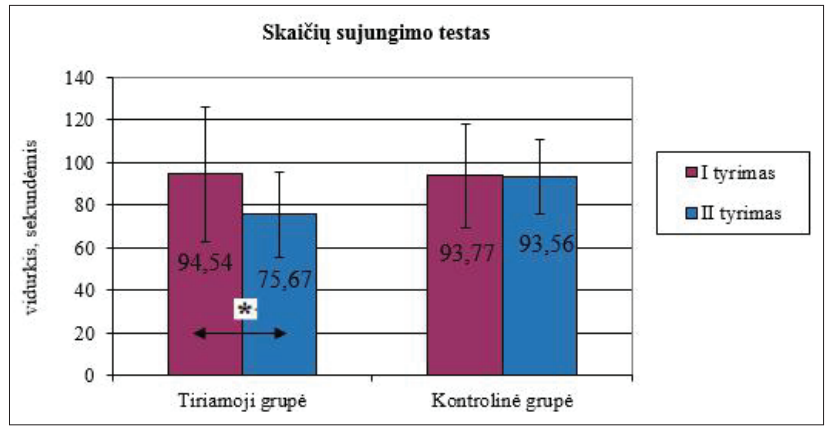

3 pav. Tyrimo dalyvių skaičių sujungimo testo rezultatai. $*_{p}<0,005$

tyrimo rezultatus.

Reakcija, dèmesys ir vykdomosios pažintinès funkcijos buvo vertinamos skaičių sujungimo testu. Išanalizavus šio testo duomenis (3 pav.), rezultatai rodo, jog taikyta fizinès veiklos programa tiriamosios grupès vykdomosioms pažintinėms funkcijoms turèjo statistiškai reikšmingą teigiamą pokyti, t.y. rezultatai po tyrimo pagerejo $8,88 \pm 9,08$ sekundèmis $(p<0,05)$. Kontrolinèje grupèje vidutinis vidurkių pokytis nebuvo statistiškai reikšmingas. Lyginant gautus rezultatus tarp tiriamosios ir kontrolinès grupių, statistikai reikšmingas skirtumas I ir II tyrimo metu nenustatytas.

\section{Diskusija}

Senyvame amžiuje atsiradus pusiausvyros, koordinacijos ir apatinių galūnių raumenų masès pakitimams, mažèja funkcinis pajėgumas, didèja griuvimų rizika $[8,9]$. İvertinus visų tiriamujų funkcini pajëgumą naudojant Trumpaji fizinès funkcijos testų rinkinį, visų tiriamujjų rezultatai I tyrimo metu buvo prasti ir nei vienas tiriamujų nesurinko maksimalaus balų skaičiaus. Bendra balų suma nesiekè 9 balų, kai maksimali balų suma yra 12 balų. Pusiau tandemineje padetyje tiriamieji buvo ịvertinti $0,90 \pm 0,295$ balu, tandeminèje padètyje $-1,43 \pm 0,55$ balu (maksimali balu suma kiekvienoje padètyje yra 2). Panašius rezultatus pateikia ir Era P. su bendraautoriais savo tyrime nagrinèję tiriamujų rezultatus tose pačiose minètose padètyse. Autoriai nagrinejo 40-49 metų ir 60 metų ir vyresnių dalyvių rezultatus [10]. Remdamiesi savo rezultatais mokslininkai teigia, jog gebejjimas išlaikyti pusiausvyrą vienoje padètyje su amžiumi prastėja ypač tų asmenų, kuriems yra per 60 metų. Taip pat tyrime gauti rezultatai įrode, jog nelavinant fizinių ypatybių šie rezultatai palaipsniui silpnejja [11].

Analizuojant tyrimo dalyvių gebejimą išlaikyti pusiausvyrą pusiau tandemineje ir tandeminèje padètyje, nustatyta, kad 8 savaičių taikomosios fizinès veiklos programa, pagrịsta koordinacijos ir pusiausvyros lavinimu, reikšmingai pagerina šių užduočių rezultatus. 
Ėjimo greitis buvo įvertintas atlikus keturių metrų èjimo užduotị, kuri atspindi bendraji judrumą ir manevringumą. Tai svarbu nepriklausomumui kasdieninėje veikloje, atsistojimui nuo kèdès, išlipimui iš autobuso, gebejimui laiku pakelti telefono rageli, prieiti atidaryti duris, nueiti i vonios kambarị ar dirbti virtuvejje ir panašiai. Atliekant ši testą galima nustatyti riziką pasikartojantiems kritimams [12]. Pirmo tyrimo metu tiriamujų eisenos greitis nesiskyrè lyginant tarp grupiu ir buvo iqvertintas $2,80 \pm 0,54$ balais iš 4 galimų. Garcia-Pinillos su bendraautoriais teigia, kad èjimo greitis parodo vyresnių nei 65 metų amžiaus žmonių funkcinį pajėgumą (fizines ir kognityvines funkcijas) [13]. Pusiauvyros ir koordinacijos pratimai padidino ejjimo greiti, vadinasi, galima teigti, kad senyvo amžiaus žmonių funkcinis pajègumas taip pat pagerèjo.

Grupeje, kuriai buvo taikomi specialūs pusiausvyros ir koordinacijos pratimai, po programos statistiškai reikšmingai pagerejo ne tik eisenos greičio rezultatai, bet ir apatinių galūnių raumenų jẻga. Atsistojimo nuo kẻdès testas yra informatyvus metodas nustatant apatinès kūno dalies raumenų jëgą pagyvenusiems žmonèms [14], vertinant kritimo riziką [15]. Vyresnio amžiaus žmonių gebėjimą judèti apsprendžia apatinès kūno dalies jèga. Pakankama jëga padeda išvengti ir atitolinti neveiksnumą, mobilumo netekimą. Apatinès kūno dalies jègos mažèjimas yra susijęs su tokių funkcinių atlikimų, kaip eisenos, lipimo laiptais, išlipimo iš automobilio, pusiausvyros pablogèjimu ir sutrikimais. Granacher U. su bendraautoriais teigia, jog eisenos ir pusiausvyros sutrikimai, vyresnio amžiaus žmonėms pasireiškiantys dèl susilpnejjusio gebėjimo atsistoti, sumažejusio laikotarpio išlaikyti statinę pusiausvyrą yra susiję su susilpnejjusia apatinių galūnių raumenų jèga ir raumenų mase [16]. Fatouros G. su kolegomis savo tyrime pastebi, jog senyvame amžiuje labai svarbu palaikyti pusiausvyrą, koordinaciją ir apatinių galūnių raumenų jègą bei jas lavinti [17]. Šiai minčiai pritaria Era P. su bendraautoriais, kurie savo tyrimo metu nagrinèję senyvo amžiaus asmenų fizinę būklę, pusiausvyrą ir koordinaciją

Bowling su bendraautoriais remdamiesi savo atlikto tyrimo duomenimis, teigia, jog fizinè veikla turi teigiamą poveikị ne tik fizinėms ypatybėms ir funkciniam pajègumui, bet ir kognityvinèms funkcijoms, kurios yra ypač svarbios vyresniame amžiuje [18]. Šiame atliktame tyrime, kurio metu buvo vertinamos objektyvios ir subjektyvios kognityvinès funkcijos, testų rezultatai statistiškai reikšmingai pagerejo po pusiausvyros ir koordinacijos lavinimo tiriamojoje grupeje. Hernan Ponce-Bravo su bendraautoriais teigia, kad jègos pratimai naudojant elastinę gumą turi didesni poveikị senyvo amžiaus žmonių fiziniam pajègumui ir kognityvinėms funkcijoms, nei ị rekreaciją orientuoti pratimai [19]. Nustatyta, kad aerobinès ištvermès ir jègos treni- ruotès yra efektyvios gerinant kognityvines funkcijas [20]

Hohman T.J. su bendraautoriais teigia, jog subjektyviai vertinami kognityviniai pokyčiai yra labai susiję su žodine atmintimi, t.y. kuo prasčiau asmuo subjektyviai vertina savo kognityvines funkcijas, tuo prastesni jo rezultatai atliekant objektyvias užduotis ir atvirkščiai [21]. Šio tyrimo rezultatai parodé, kad tiriamieji, dalyvavę taikomojoje fizinejje veikloje, geriau ịvertino savo subjektyvias kognityvines funkcijas ir geriau bei greičiau atliko objektyvias kognityvinių funkcijų užduotis, nei tie, kurie nebuvo fiziškai aktyvūs. Moksliniais tyrimais nustatyta, kad fiziškai aktyvūs senyvo amžiaus žmonés pasižymi geresnemis kognityvinèmis funkcijomis nei fiziškai pasyvūs [22].

\section{Išvados}

1. Tiriamosios grupès funkcinis pajëgumas po pusiausvyros ir koordinacijos pratimų statistiškai reikšmingai pagerèjo. Kontrolinèje grupejje pokyčio nenustatyta.

2. Statistiškai reikšmingai pagerèjo subjektyvių ir objektyvių kognityvinių funkcijų rezultatai tiriamojoje grupeje bei lyginant rezultatus tarp grupių II tyrimo metu. Visų tiriamujų trumpalaikè ir ilgalaikè atmintis nepakito, tačiau rastas skirtumas tarp grupių II tyrimo metu $(\mathrm{p}<0,05)$; vykdomųjų kognityvinių funkcijų rezultatai pakito tik tiriamojoje grupeje $(\mathrm{p}<0,05)$;

\section{Literatūra}

1. Backman L, Lindenberger U, Li S, Nyberg L. Linking cognitive aging to alterations in dopamine neurotransmitter function-ing: recent data and future avenues. Neurosci Biobehav. Rev 2010; 34:670-677.

http://dx.doi.org/10.1016/j.neubiorev.2009.12.008

2. Lovden, M, Backman L, Lindenberger U, Schafer S, Schmiedek F. A theoretical framework for the study of adult cognitive plasticity. Psychol Bull 2010; 136:659-676.

http://dx.doi.org/10.1037/a0020080

3. Vogel T, Brechat P, Lepretre PM et al. Health benefits of physical activity in older patients: a review. International Journal of Clinical Practice 2009; 63:303-320.

http://dx.doi.org/10.1111/j.1742-1241.2008.01957.x

4. Poon CY, Fung HH. Physical activity and psychological wellbeing among Hong Kong Chinese older adults: exploring the moderating role of self-construal. The International Journal of Aging and Human Development 2008; 66:1-19.

http://dx.doi.org/10.2190/AG.66.1.a

5. Chih-Hsuan Chou, Chueh-Lung Hwang, Ying-Tai Wu. Effect of exercise on physical function, daily living activities, and quality of life in the frail older adults: a meta-analysis. Archives of Physical Medicine and Rehabilitation 2012, 93(2): 237-244 http://dx.doi.org/10.1016/j.apmr.2011.08.042

6. Lustig C, Shah P, Seidler R, Reuter- Lorenz PA. (2009). Aging, training, and the brain: a review and future directions. Neu- 
ropsychol. Rev 2009; 19:504-522.

http://dx.doi.org/10.1007/s11065-009-9119-9

7. Shephard RJ, Cox MH, Simper K. et al. An analysis of "Par-Q" responses in an office population. Canadian Journal of Public Health 1981; 72: 37-40.

8. Ward RE, Leveille SG, Beauchamp MK. et al. Functional performance as a predictor of injurious falls in older adults. Journal of the American Geriatrics Society 2015; 63(2):315-320 http://dx.doi.org/10.1111/jgs.13203

9. Tinetti ME, Kumar C. The patient who falls: "It's always a trade-off" JAMA 2010; 303:258-266.

http://dx.doi.org/10.1001/jama.2009.2024

10. Era P, Sainio P, Koskinen S. et al. "Postural balance in a random sample of 7,979 subjects aged 30 years and over," Gerontology 2006; 4:204-213.

http://dx.doi.org/10.1159/000093652

11. Abrahamova D, Hlavacka F. Age-related changes of human balance during quiet stance. Physiological research Academia Scientiarum Bohemoslovaca 2008; 57(6):957-964.

12. Nelson ME, Jack Rejeski W, Blair SN, et al. Physical activity and public health in older adults recommendation from the American College of Sports Medicine and the American Heart Association. Circulation 2007, 116:1094-1105.

http://dx.doi.org/10.1161/CIRCULATIONAHA.107.185650

13. Garcia-Pinillos F, Cozar-Barba M, Munoz-Jimenez M, SotoHermoso V, Latorre-Roman P. Gait speed in older people: an easy test for detecting cognitive impairment, functional independence, and health state 2015, 26.

14. McCarthy, EK, Horval, MA, Wisenbaker, JM, and Holtsberg, PA. Repeated chair stands as a measure of lower limb strength in sexagenarian women. J Geront A Biol Sci Med Sci 2004, 59:1207-1212.

15. Yuan-Yang Cheng, Shun-Hwa Wei, Po-Yin Chen et al. Can sit-to-stand lower limb muscle power predict fall status? Gait \& Posture 2014, 40(3): 403-407

http://dx.doi.org/10.1016/j.gaitpost.2014.05.064

16. Granacher U, Bridenbaugh SA, Muehlbauer TA. et al. Age related effects on postural control under multi-task conditions. Journal of Gerontology 2011, 57:247-255

http://dx.doi.org/10.1159/000322196

17. Fatouros G, Taxildaris K, Tokmakidis SP. et al. The effects of strength training, cardiovascular training and their combination on flexibility of inactive older adults. Int J Sports Med 2002, 23(2):112-119

http://dx.doi.org/10.1055/s-2002-20130

18. Bowling AC, Lindsay P, Smith BG, et al. Saccadic eye movements as indicators of cognitive function in older adults. Neuropsychology, development, and cognition Section B, Aging, Neuropsychology and Cognition 2015, 22(2):201-19 http://dx.doi.org/10.1080/13825585.2014.901290

19. Ponce-Bravo H, Ponce C, Feriche B, Padial P. Influence of two different exercise programs on physical fitness and cognitive performance in active older adults: functional resistance-band exercises vs. Recreational oriented exercises. Journal of Sport Science and Medicine 2015, 14:716-722.

20. Barnes DE, Yaffe K, Satariano WA, Tager IB. A longitudinal study of cardiorespiratory fitness and cognitive function in healthy older adult. Journal of the American Geriatrics Society 2003; 51(4):459-465.

http://dx.doi.org/10.1046/j.1532-5415.2003.51153.x

21. Hohman TJ, Lamar M, Beason - Held L. et al. Subjective cognitive complaints and longitudinal changes in memory and brain function. Neuropsychology 2011, 1:125-130

http://dx.doi.org/10.1037/a0020859

22. Renaud M, Bherer L, Maquestiaux F. A high level of physical fitness is associated with more efficient response preparation in older adults. Journals of Gerontology B 2010, 65(3): 317-322. http://dx.doi.org/10.1093/geronb/gbq004

\section{BALANCE AND COORDINATION EXERCISES IM- PROOVE FUNCTIONAL PERFORMANCE AS WELL AS COGNITIVE FUNCTION IN OLDER ADULTS} I. Muntianaitė, F. Blužaitė, J. Indriūnienė, R. Žilinskienė, A. Nainaitè

Key words: older people, balance and coordination exercises, functional performance, cognitive functions

Summary

The purpose of the research is to establish impact of applied physical activities based by balance and coordination exercises on functional performance and cognitive functions in elderly.

Participants in research: Forty older adults took part in the research. The average age of participants was initially 71,6 $\pm 6,9$ years. Participants were devided into two groups: study group gymnastic exercises group $(n=20$, age $71,35 \pm 6,52$ years $)$ and control group - people without gymnastic exercises $(n=20,73,55$ $\pm 5,47$ years).

The methods of research: short physical performance battery; 5 words test; trail making test; six item cognitive impairment test; the cognitive failures questionnaire.

Results and conclusions. The results of functional performance in experimental group has increased more $(p<0,05)$ than in control group after balance and coordination training: at the end of the reasearch the total score of Short Physical Performance Bartery in experimental group was $11,80 \pm 1,06$ score, in control group $8,95 \pm 1,15$ score $(p<0,05)$. The results of objective and subjective cognitive functions in experimental group has increased statistically significantly more than in control group; the results of short-term memory and long-term memory were better in experimental group than in control group $(p<0,05)$ in the end of the research. The results of Trail Making Test in experimental gruop has increased during the research $(p<0,05)$, however no significantly differences was found between groups.

The findings demonstrate that applied physical activity program, prepared for balance and coordination training, positively affects functional capasity and cognitive functions in elderly.

Correspondence to: inga.muntianaite@mf.vu.lt

Gauta 2016-05-18 